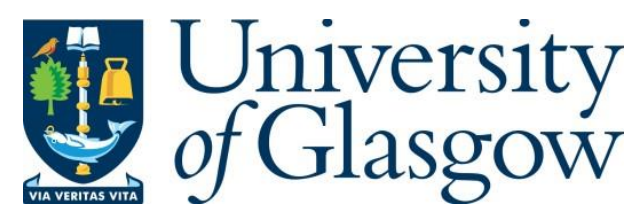

Pedersen, M. W. et al. (2016) Postglacial viability and colonization in North America's ice-free corridor. Nature, 537(7618), pp. 45-49.

There may be differences between this version and the published version. You are advised to consult the publisher's version if you wish to cite from it.

http://eprints.gla.ac.uk/138297/

Deposited on: 16 August 2016

Enlighten - Research publications by members of the University of Glasgow http://eprints.gla.ac.uk 


\section{Postglacial viability and colonization in North America's ice-free corridor}

2 Mikkel Winther Pedersen ${ }^{1}$, Anthony Ruter ${ }^{1}$, Charles Schweger ${ }^{2}$, Harvey Friebe ${ }^{2}$,

3 Richard A. Staff ${ }^{3}$, Kristian K. Kjeldsen ${ }^{1,4}$, Marie Lisandra Zepeda Mendoza ${ }^{1}$,

4 Alwynne B. Beaudoin ${ }^{5}$, Cynthia Zutter ${ }^{6}$, Nicolaj Krog Larsen ${ }^{1,7}$, Ben A. Potter ${ }^{8}$,

5 Rasmus Nielsen ${ }^{9,10}$, Rebecca A. Rainville ${ }^{11}$, Ludovic Orlando ${ }^{1}$, David J. Meltzer ${ }^{1,12}$,

6 Kurt H. Kjær ${ }^{1}$, and Eske Willerslev ${ }^{1,13,14^{*}}$

$7{ }^{1}$ Centre for GeoGenetics, Natural History Museum, University of Copenhagen,

8 Copenhagen, Denmark.

$9 \quad{ }^{2}$ Department of Anthropology, University of Alberta, Edmonton, Alberta, Canada.

$10{ }^{3}$ School of Archaeology, University of Oxford, Oxford, UK.

$11{ }^{4}$ Department of Earth Sciences, University of Ottawa, Ottawa, Ontario, Canada

$12 \quad{ }^{5}$ Royal Alberta Museum, Edmonton, Alberta, Canada.

$13{ }^{6}$ Department of Anthropology, MacEwan University, Edmonton, Alberta, Canada.

$14 \quad{ }^{7}$ Department of Geoscience, Aarhus University, Aarhus, Denmark.

$15{ }^{8}$ Department of Anthropology, University of Alaska Fairbanks, Alaska, USA.

$16{ }^{9}$ Department of Integrative Biology, University of California, Berkeley, USA

$17 \quad{ }^{10}$ Department of Biology, University of Copenhagen, Copenhagen, Denmark

$18{ }^{11}$ Department of Archaeology, University of Calgary, Calgary, Alberta, Canada.

$19{ }^{12}$ Department of Anthropology, Southern Methodist University, Dallas, Texas, USA.

$20{ }^{13}$ Department of Zoology, University of Cambridge, Cambridge, UK.

$21{ }^{14}$ Wellcome Trust Sanger Institute, Cambridge, UK.

22 *Corresponding author: ewillerslev@snm.ku.dk 
1 Abstract

2 During the Last Glacial Maximum, continental ice sheets isolated Beringia

3 (northeast Siberia and northwest North America) from unglaciated North

4 America. By around 15 to 14 thousand calibrated radiocarbon years before

5 present (cal. kyr BP), glacial retreat opened an approximately 1,500-km-long

6 corridor between the ice sheets. It remains unclear when plants and animals

7 colonized this corridor and it became biologically viable for human migration.

8 We obtained radiocarbon dates, pollen, macrofossils and metagenomic DNA

9 from lake sediment cores in a bottleneck portion of the corridor. We find

10 evidence of steppe vegetation, bison and mammoth by approximately $12.6 \mathrm{cal}$.

11 kyr BP, followed by open forest, with evidence of moose and elk at about 11.5 cal.

12 kyr BP, and boreal forest approximately 10 cal. kyr BP. Our findings reveal that

13 the first Americans, whether Clovis or earlier groups in unglaciated North

14 America before $\mathbf{1 2 . 6}$ cal. kyr BP, are unlikely to have travelled by this route into

15 the Americas. However, later groups may have used this north-south

16 passageway. 


\section{1}

3 Understanding the postglacial emergence of an unglaciated and biologically viable

4 corridor between the retreating Cordilleran and Laurentide ice sheets is a key part of

5 the debate on human colonization of the Americas ${ }^{1,2,3}$. The opening of the ice-free

6 corridor, long considered the sole entry route for the first Americans, closely precedes

7 the 'abrupt appearance' of Clovis, the earliest widespread archaeological complex

8 south of the ice sheets at $\sim 13.4$ cal. $\mathrm{kyr} \mathrm{BP}^{4,5}$. This view has been challenged by recent

9 archaeological evidence that suggests people were in the Americas by at least 14.7

10 cal. $\mathrm{kyr} \mathrm{BP}^{6,7}$, and possibly several millennia earlier ${ }^{8}$. Whether this earlier presence

11 relates to Clovis groups remains debated ${ }^{9}$. Regardless, as it predates all but the oldest

12 estimates for the opening of the ice-free corridor ${ }^{10,11}$, archaeological attention has

13 shifted to the Pacific coast as an alternative early entry route into the Americas ${ }^{1,11}$.

14 Yet, the possibility of a later entry in Clovis times through an interior ice-free corridor 15 remains open ${ }^{1,9,12}$.

17 Whether the ice-free corridor could have been used for a Clovis-age migration depends on when it became biologically viable. However, determining this has proven

19 difficult because radiocarbon and luminescence dating of ice retreat yield conflicting

20 estimates for when the corridor opened, precluding precise reconstruction of

21 deglaciation chronology ${ }^{10}, 13,14,15,16,17$. Once the landscape was free of ice and

22 meltwater, it was open for occupation by plants and animals, including those

23 necessary for human subsistence. On the basis of studies on modern glaciers ${ }^{18}$, the

24 onset of biological viability could have been brief (for example, a few decades) if 
1 propagules were available in adjacent areas, and assuming they were capable of

2 colonizing what would have been a base-rich (high $\mathrm{pH}$ ) and nitrogen-poor, soil

3 substrate (such as nitrogen-fixing plants like Shepherdia canadensis (buffaloberry)).

5 Establishment of biota within the corridor region must have varied locally depending

6 on the rate and geometry of ice retreat, the extent of landscape flooding under

7 meltwater lakes, and the proximity of plant and animal taxa and their dispersal

8 mechanisms ${ }^{1,19,20}$. Some areas were habitable long before others. Although the

9 corridor's deglaciation history was complex, broadly speaking it first opened from its

10 southern and northern ends, leaving a central bottleneck that extended from

11 approximately $55^{\circ} \mathrm{N}$ to $60^{\circ} \mathrm{N}^{1,10,13,14,15,21}$. On the basis of currently available

12 geological evidence, this was the last segment to become ice free and re-colonized by

13 plants and animals ${ }^{1,13,22,23,24 .}$

15 Although palynological and palaeontological data can be used to help study the

16 opening of the corridor region, these are limited in several respects. First, not all

17 vegetation, particularly pioneering forbs and shrubs, produce pollen and macrofossils

18 with good preservation potential that will be detectable in available depositional

19 locales. Hence, timing of plants' appearance may be underestimated. Second, pollen

20 can disperse over long distances and have limited taxonomic resolution, differential

21 preservation, and variable production rates, all of which can bias vegetation reconstruction ${ }^{25}$. Third, fossil evidence for initial large mammal populations that

23 dispersed into the newly opened corridor is sparse. The fossil remains suggest the

24 presence of bison, horse and mammoth, and probably some camel, muskox and 
1 caribou $^{26,27}$. Yet, the oldest vertebrate remains after the Last Glacial Maximum are no

2 older than $\sim 13.5$ cal. $\mathrm{kyr} \mathrm{BP}^{2}$, and those specimens are found outside the bottleneck

3 region ${ }^{1,3,26,28,29}$. These animals would have been the source populations to recolonize

4 the newly opened landscape, and thus their presence within the bottleneck region can

5 indicate when the corridor became a viable passageway over its entirety.

\section{$7 \quad$ Samples and analytical approaches}

8 To overcome current limitations of the palaeoecological record, and develop a more

9 precise chronology for the opening and biological viability of corridor's bottleneck

10 region, we collected nine lake sediment cores from Charlie Lake and Spring Lake in

11 the Peace River drainage basin (Fig. 1). These are remnants of Glacial Lake Peace,

12 which formed as the Laurentide Ice Sheet began to retreat in this region around 15 to

1313.5 cal. kyr BP and blocked eastward draining rivers ${ }^{10,13,14,15,21}$ (Extended Data Fig.

14 1). Glacial Lake Peace flooded the gap between the ice fronts until about 13 cal. kyr BP, 15 sometime after which Charlie and Spring lakes became isolated ${ }^{13}$. Thus, this area was 16 amongst the last segments of the corridor to open and is pivotal to understanding its

17 history as a biogeographic passageway ${ }^{1,13,14,16,22,24 .}$

18 Of the nine cores obtained from Charlie Lake and Spring Lake, one from each lake 19 predates the Pleistocene to Holocene transition, the oldest dating to $\sim 12.9$ cal. kyr BP 20 (modelled age). We sampled the cores from both lakes for magnetic susceptibility, 21 pollen ${ }^{30,31}$, micro- and macrofossils, including ${ }^{14} \mathrm{C}$-dateable material for subsequent 22 robust Bayesian age-depth modelling (Fig. 2, Methods, Extended Data Figs 2, 3, 4 and 23 Supplementary Information). In addition, we obtained environmental DNA (eDNA) ${ }^{32}$, 24 representing molecular fossils of local organisms derived from somatic tissues, urine 
1 and faeces ${ }^{33}$, but rarely pollen ${ }^{34}$. eDNA complements traditional pollen and macrofossil

2 studies $^{35}$, and is especially useful for establishing the likelihood that a taxon occurred

3 within a particular time period ${ }^{36,37}$. Furthermore, eDNA enables identification of taxa

4 even in the absence of micro- and macrofossil material, thus improving the resolution

5 of taxonomic richness surveys ${ }^{36}$. However, amplification of short and taxonomically

6 informative DNA metabarcodes ${ }^{38}$ can be biased towards taxa targeting ${ }^{35}$. We used

7 shotgun sequencing of the full metagenome in the DNA extracts to reveal the whole

8 diversity of taxonomic groups present in the sediment ${ }^{39}$ (Fig. 2, Methods, Extended

9 Data Figs 5 and 6 and Supplementary Information). We confirmed the sequences

10 identified as ancient by quantifying DNA damage ${ }^{40}$, and found the DNA damage levels

11 to accumulate with age (Pearson correlation coefficient $=0.663, \mathrm{P}$ value $=0.00012$ )

12 (Methods and Extended Data Fig. 7a, b).

\section{Biological succession within the corridor bottleneck}

15 The basal deposit in the Charlie Lake core is proglacial gravel, previously reported from

16 the area $^{22}$, above which are laminated lacustrine sediments, principally composed of

17 silt-sized grains ${ }^{24}$ (Extended Data Fig. 2). We interpret these as deposits from Glacial

18 Lake Peace Stage IV (ref. 13), the $>15,000 \mathrm{~km}^{2}$ proglacial lake that covered the Peace

19 River area of northeastern British Columbia and northwestern Alberta. A subsequent

20 lithological change from silt to sandy organic rich mud (gyttja) at the onset of Holocene,

21 around 11.6 cal. kyr BP, reflects a change in sediment source and lake productivity we

22 interpret as Charlie Lake becoming isolated from Glacial Lake Peace (Fig. 1). This is

23 followed by a decrease in pollen influx in both lake records at $\sim 11.5 \mathrm{cal}$. kyr BP that

24 coincides with an increase in pre-Quaternary palynomorphs. At Charlie Lake there is

25 then a marked increase in pollen influx at $\sim 11.3$ cal. kyr BP. We interpret these 
1 fluctuations as responses of a highly dynamic landscape to paraglacial and aeolian

2 redepositional processes.

4 Our palynological and eDNA-based taxonomic identifications, respectively, reveal the

5 development of biota in the regional and local environment surrounding each lake (Fig.

6 2, Extended Data Figs 3, 4, 5, 6). Prior to 12.6 cal. kyr BP (Charlie Lake, pollen zone

7 I, 13 to 12.6 cal. kyr BP), the bottleneck area appears to have been largely unvegetated,

8 receiving low pollen influx $\left(<50\right.$ grains $\left.\mathrm{cm}^{-2} \mathrm{y}^{-1}\right)$ with little organic content

9 (incoherent/coherent ratio) and low DNA concentrations ( $<5 \mathrm{ng}$ per g of sediment).

10 During the later phases of Glacial Lake Peace, both pollen and eDNA indicate grasses

11 and sedges were early colonizers. Charlie Lake pollen zone II ( 12.6 to 11.6 cal. kyr

12 BP) contains evidence of steppe vegetation, including Artemisia (sagebrush),

13 Asteraceae (sunflower family), Ranunculaceae (buttercup family), Rosaceae (rose

14 family, rosids in eDNA), Betula (birch), and Salix (willow). A similar plant community

15 is recorded at Spring Lake (pollen zone 1), with substantial abundances of Populus and

16 S. canadensis, probably due to elevation differences and because by this time Spring

17 Lake was no longer part of the Glacial Lake Peace system.

eDNA indicates the steppe vegetation supported a variety of animals including Bison which appear at $\sim 12.5$ cal. kyr BP, and Microtus (vole) and Lepus (jackrabbit) by $\sim 12.4$

21 cal. kyr BP (Fig. 3). After 12.4 cal. kyr BP, Populus trees became more dominant and

22 Cervus (elk), Haliaeetus (bald eagle) and Alces (moose) appear in the eDNA record.

23 The productivity of the bottleneck increased to a peak at $\sim 11.6$ cal. kyr BP. The presence 24 of Esox (pike), a top aquatic predator, implies that by $\sim 11.7$ cal. kyr BP, a fish 25 community was already established. After 11.6 cal. kyr BP, Picea (spruce), Pinus (pine) 
1 and Betula pollen increased in the Charlie Lake pollen record, reflecting the

2 establishment of boreal forest.

3 Around 11.5 cal. kyr BP, a distinct decline occurred in pollen influx at both lakes. High

4 abundance of Botryococcus (green algae) in each is probably a response to changing

5 nutrient sources, lake chemistry, sediment input and possibly reduced turbidity

6 following isolation of these basins from Glacial Lake Peace41. Botryococcus

7 dominated the early Holocene sequence in Spring Lake (11.7-11.5 cal. kyr BP) but

8 declined relative to Pediastrum (green algae) after 11.0 cal. kyr BP, consistent with

9 eutrophication in a more productive ecosystem. Pollen and plant macrofossils indicate

10 Alnus (alder) was in the vicinity of Spring Lake at about 7.0 cal. kyr BP, although it is

11 not evident in eDNA until approximately 5.5 cal. kyr BP.

13 We used non-metric multi-dimensional scaling (NMDS) based on Bray-Curtis

14 similarity measures to explore whether the eDNA plant communities, excluding algae,

15 reflect the pollen data (Fig. 2b, d). In eDNA samples, the first NMDS axis matches the

16 clear separation between major pollen zones at Spring Lake and Charlie Lake. The only

17 exception is represented by the 12.2 cal. kyr BP sample at Charlie Lake, which does not

18 cluster with other samples of similar age ( 12.6-11.6 cal. kyr BP) but is closer to the

19 arboreal and younger samples from pollen zone I. Nevertheless, consistency between

20 the main pollen zones and clustering of eDNA samples confirms that large ecological

21 changes found in pollen records can be identified using eDNA.

23 Despite good conformity between palynological and eDNA data, some discrepancies

24 suggest these proxies are variably affected by a plant's reproductive process and 25 taphonomic history (see Supplementary Information). The most notable of these 
1 discrepancies is the Populus record. In Charlie Lake, its pollen and eDNA signals are

2 congruent from $\sim 11.6-11.2$ cal. kyr BP, whereas earlier ( 12.4-12.1 cal. kyr BP) the

3 eDNA signal for Populus is more pronounced. In Spring Lake, Populus pollen only

4 occurs towards the base of the record and in upper zone III, whereas in the eDNA record

5 it is abundant throughout. This discrepancy is probably due to Populus reproducing

6 vegetatively, and its notoriously low detection rates and poor pollen preservation,

7 which often render it palynologically 'silent ${ }^{\text {,2 }}$. The eDNA reveals that poplar was

8 probably more abundant in the regional vegetation than has previously been shown with

9 palynology. This has important implications for human occupation as poplar would

10 have provided wood for fuel, shelter, and tools, as well as browse feeding for animals.

12 The differences between the pollen and eDNA evidence for plants might also reflect

13 dispersal factors. Wind-dispersed pollen is more likely to be encountered in lake-based

14 pollen records, whereas predominantly insect-pollinated taxa are less likely to settle in

15 lake sediments and be detected. Many willows (Salix spp.), for example, are insect

16 pollinated. Their pollen is present in low percentage (5\%) in zone II in Charlie Lake,

17 but in higher abundance in zones II and III in the eDNA record (Extended Figs 5 and

18 6). This suggests the eDNA comes more from macrofossils and plant debris than from 19 pollen.

21 The eDNA record also detects taxa not present in fossil bone assemblages, including terrestrial and aquatic vertebrates. In particular, it identifies top-level aquatic (Esox)

23 and avian (Haliaeetus) predators, which indicate a rich supporting community at lower

24 trophic levels. Cervus is evident in the Charlie Lake record at about 11.5 cal. kyr BP, 25 whereas its earliest fossil remains from the area date to about $10.2 \mathrm{cal}$. $\mathrm{kyr} \mathrm{BP}^{43}$. Small 
1 mammals, such as Microtus are documented in the Charlie Lake eDNA at 12.4 cal. kyr

2 BP confirming the Microtus colony found just west of Charlie Lake, at Bear Flats ${ }^{43}$.

3 Yet, there are also notable absences in eDNA compared to the vertebrate record. For

4 example, faunal remains from the adjacent Charlie Lake Cave, dated to 12.4 cal. kyr

$5 \mathrm{BP}^{44}$ are rich in waterfowl and other birds and fish not detected by eDNA. In the Spring

6 Lake eDNA record, Castor (beaver) appears between 5.4 and 3 cal. kyr BP, whereas

7 evidence from Wood Bog ${ }^{45} \sim 60 \mathrm{~km}$ to the south suggests that the beaver was part of

8 the local fauna since at least 11 cal. kyr BP.

10 When the evidence from these multiple proxies is combined, it provides a more robust

11 record of the presence of plants and animals than any single indicator. It is, of course, 12 possible that some taxa arrived on the landscape earlier and escaped detection, thus 13 appearing absent. However, there was only a narrow window of time between when the 14 bottleneck region was beneath the waters of Glacial Lake Peace and impassable, and 15 when these proxies first detect the presence of plants and animals. The eDNA data are 16 particularly important for indicating the earliest occurrence of terrestrial fauna in the 17 bottleneck region, particularly the game animals that would have been key subsistence 18 resources for hunter-gatherers ${ }^{46}$.

\section{Discussion}

22 Although ice sheet retreat led to the corridor physically opening in the bottleneck region 23 starting around $15-14$ cal. $\mathrm{kyr} \mathrm{BP}^{10}$, deglaciation was followed by regional inundation 24 below the waters of Glacial Lake Peace for perhaps up to 2,000 years ${ }^{13}$. By around 12.6 25 cal. kyr BP the ice sheets were several hundred kilometres apart and the landscape had 
1 become vegetated. Large and small animals came in soon thereafter, around 12.5 cal.

2 kyr BP, making the corridor capable of supplying the biotic resources, including high-

3 ranked prey such as bison, required by human foragers for the $1,500 \mathrm{~km}$ traverse $\mathrm{e}^{47}$. This

4 result is consistent with the recent finding that the oldest of the southern bison clade

5 specimens (clades $1 \mathrm{a}$ and $2 \mathrm{~b}$ ) found north of the bottleneck region postdates $12.5 \mathrm{cal}$.

6 kyr BP, though not with the finding that it opened earlier ${ }^{3}$ (see Supplementary 7 Information).

9 From our findings, it follows that an ice-free corridor was unavailable to those groups 10 who appear to have arrived in the Americas south of the continental ice sheets by 14.7

11 cal. kyr $\mathrm{BP}^{6,7}$, and also opened too late to have served as an entry route for the ancestors 12 of Clovis who were present by $13.4 \mathrm{cal}$. $\mathrm{kyr} \mathrm{BP}^{1,9}$. Not surprisingly, the earliest 13 archaeological presence in the Peace River region, at Charlie Lake Cave (Fig. 3) and 14 Saskatoon Mountain ${ }^{45,47}$, postdates 12.6 cal. kyr BP. More striking, once opened, the 15 corridor was not used just for southbound movement: archaeological evidence suggests 16 that people were moving north as well, potentially renewing contact between groups that had been separated for millennia ${ }^{1,9}$. Bison ${ }^{3}$ were also colonizing the corridor and moving north and south; it is uncertain whether other species, such elk ${ }^{2}$ and brown 19 bears $^{48}$, were moving similarly.

21 More broadly, although Clovis people may yet be shown to represent an independent 22 migration separate from the peoples present here by 14,700 cal. kyr BP, they must have 23 descended from a population that entered the Americas via a different route than the 24 ice-free corridor. This conclusion is relevant to the recent finding ${ }^{49}$ that ancestral Native 25 Americans diverged into southern and northern branches $\sim 13$ cal. kyr BP (95\% 
1 confidence interval of 14.5-11.5 cal. kyr BP). This implies that if that split occurred

2 north of the ice sheets, there must have been two pulses of migration to the south. As

3 the Anzick infant's genome, dated to $12.6 \mathrm{cal}$. kyr BP and associated with Clovis

4 artefacts, is part of the southern branch ${ }^{50}$, its ancestors must have travelled via the coast.

5 However, this does not preclude the possibility that ancestors of the northern branch

6 left Alaska later, through a then-viable ice-free corridor. Alternatively, if the divergence

7 occurred in unglaciated North America, as recently proposed ${ }^{49}$, it implies a single

8 ancestral population came via the coast. It further raises the possibility that the northern

9 branch — the descendants occupying Alaska today—made their way north to Alaska via

10 the corridor after 12.6 cal. kyr BP. Further investigations of ancient DNA may help

11 resolve this issue.

Methods

15 Sediment sampling. We obtained 23 sediment cores from 8 different lakes by using a 16 percussion corer deployed from the frozen lake surface ${ }^{51}$. To prevent eventual internal 17 mixing, we discarded all upper suspended sediments and only kept the compacted 18 sediment for further investigation. Cores were cut into smaller sections to allow 19 transport and storage. All cores were taken to laboratories at the University of Calgary 20 and were stored cold at $5{ }^{\circ} \mathrm{C}$ until subsequent subsampling. Cores were split using an 21 adjustable tile saw, cutting only the PVC pipe. The split half was taken into a positive 22 pressure laboratory for DNA subsampling. DNA samples were taken wearing full body 23 suit, mask and sterile gloves; the top $10 \mathrm{~mm}$ were removed using two sterile scalpels 24 and samples were taken with a $5 \mathrm{ml}$ sterile disposable syringe $\left(3-4 \mathrm{~cm}^{2}\right)$ and transferred 25 to a $15 \mathrm{ml}$ sterile spin tube. Caution was taken not to cross-contaminate between layers 
1 or to sample sediments in contact with the inner side of the PVC pipe. Samples were

2 taken every centimetre in the lowest $1 \mathrm{~m}$ of the core (except for Spring Lake, the lowest

$32 \mathrm{~m}$ ), then intervals of $2 \mathrm{~cm}$ higher up, and finally samples were taken every $5 \mathrm{~cm}$, and

4 subsequently frozen until analysed. Pollen samples were taken immediately next to the

5 DNA samples, while macrofossil samples were cut from the remaining layer in $1 \mathrm{~cm}$ or

$62 \mathrm{~cm}$ slices. Following sampling, the second intact core halves were visually described

7 and wrapped for transport. All cores were stored at $5{ }^{\circ} \mathrm{C}$ before, during and after

8 shipment to the University of Copenhagen (Denmark).

10 Core logging and scanning. An ITRAX core scanner was used to take high-resolution 11 images and to measure magnetic susceptibility at the Department of Geoscience, 12 Aarhus University. Magnetic susceptibility ${ }^{52}$ was measured every $0.5 \mathrm{~cm}$ using a 13 Bartington Instruments MS2 system (Extended Data Fig. 2).

Pollen and macrofossil extraction and identification. Pollen was extracted using a 16 standard protocol $^{30}$. Lycopodium markers were added to determine pollen 17 concentrations ${ }^{53}$ (see Supplementary Information). Samples were mounted in (2000 cs) 18 silicone oil and pollen including spores were counted using a Leica Laborlux-S 19 microscope at $400 \times$ magnification and identified using keys ${ }^{30,53,54}$ as well as reference 20 collections of North American and Arctic pollen housed at the University of Alberta 21 and the Danish Natural History Museum, respectively. Pollen and pteridophyte spores 22 were identified at least to family level and, more typically, to genera. Green algae 23 coenobia of Pediastrum boryanum and Botryococcus were recorded to track changes 24 in lake trophic status. Pollen influx values were calculated using pollen concentrations 25 divided by the deposition rate (see Supplementary Information). Microfossil diagrams 
1 were produced and analysed using PSIMPOLL $4.10^{\text {(ref. } 31)}$. The sequences were zoned

2 with CONIIC $^{31}$, with a stratigraphy constrained clustering technique using the

3 information statistic as a distance measure. All macrofossils were retrieved using a

$4 \quad 100 \mu \mathrm{m}$ mesh size and were identified but not quantified.

6 Radiocarbon dating and age-depth modelling. Plant macrofossils identified as 7 terrestrial taxa (or unidentifiable macrofossils with terrestrial characteristics where no 8 preferable material could be identified) were selected for radiocarbon $\left({ }^{14} \mathrm{C}\right)$ dating of

9 the lacustrine sediment. All macrofossils were subjected to a standard acid-base-acid 10 (ABA) chemical pre-treatment at the Oxford Radiocarbon Accelerator Unit (ORAU), 11 following a standard protocol ${ }^{55}$, with appropriate 'known age' (that is, independently 12 dendrochronologically-dated tree-ring) standards run alongside the unknown age plant 13 macrofossil samples ${ }^{56}$. Specifically, this ABA chemical pre-treatment (ORAU 14 laboratory pre-treatment code ' $\mathrm{VV}$ ') involved successive $1 \mathrm{M} \mathrm{HCl}\left(20 \mathrm{~min}, 80^{\circ} \mathrm{C}\right)$, $150.2 \mathrm{M} \mathrm{NaOH}\left(20 \mathrm{~min}, 80^{\circ} \mathrm{C}\right)$ and $1 \mathrm{M} \mathrm{HCl}\left(1 \mathrm{~h}, 80^{\circ} \mathrm{C}\right)$ washes, with each stage 16 followed by rinsing to neutrality ( $\geq 3$ times) with ultrapure MilliQ deionised water. The three principal stages of this process (successive ABA washes) are similar across most radiocarbon laboratories and are, respectively, intended to remove: (i) sedimentary- and

19 other carbonate contaminants; (ii) organic (principally humic- and fulvic-) acid 20 contaminants; and (iii) any dissolved atmospheric $\mathrm{CO}_{2}$ that might have been absorbed 21 during the preceding base wash. Thus, any potential secondary carbon contamination 22 was removed, leaving the samples pure for combustion and graphitisation. Accelerator 23 mass spectrometry (AMS) ${ }^{14} \mathrm{C}$ dating was subsequently performed on the $2.5 \mathrm{MV}$ 24 HVEE tandem AMS system at ORAU ${ }^{57}$. As is standard practice, measurements were 25 corrected for natural isotopic fractionation by normalizing the data to a standard $\delta^{13} \mathrm{C}$ 
1 value of $-25 \%$ VPDB, before reporting as conventional ${ }^{14} \mathrm{C}$ ages before present (BP,

2 before ad 1950$)^{58}$.

$4 \quad$ These ${ }^{14} \mathrm{C}$ data were calibrated with the IntCal13 calibration curve ${ }^{59}$ and modelled using

5 the Bayesian statistical software OxCal v. 4.2 (ref. 60). Poisson process

6 ('P_Sequence' ) deposition models were applied to each of the Charlie and Spring

7 Lake sediment profiles ${ }^{61}$, with objective 'Out I i er' analysis applied to each of the

8 constituent ${ }^{14} \mathrm{C}$ determinations ${ }^{62}$. The $\mathrm{P}_{-}$Sequence model takes into account the

9 complexity (randomness) of the underlying sedimentation process, and thus provides

10 realistic age-depth models for the sediment profiles on the calibrated radiocarbon

11 (IntCal) timescale. The rigidity of the $P_{-}$Sequence (the regularity of the 12 sedimentation rate) is determined iteratively within OxCal through a model averaging 13 approach, based upon the likelihood (calibrated ${ }^{14} \mathrm{C}$ ) data included within the model ${ }^{60}$.

14 A prior 'Out I $\mathrm{i}$ er' probability of $5 \%$ was applied to each of the ${ }^{14} \mathrm{C}$ determinations, 15 because there was no reason, a priori, to believe that any samples were more likely to 16 be statistical outliers than others. All ${ }^{14} \mathrm{C}$ determinations are provided in Extended Data

17 Table 1; OxCal model coding is provided in the Supplementary Information; and plots 18 of the age-depth models derived for Spring and Charlie Lakes are given in Extended 19 Data Fig. 2.

21 DNA analysis. All DNA extractions and pre-PCR analyses were performed in the 22 ancient DNA facilities of the Centre for GeoGenetics, Copenhagen. Total genomic 23 DNA was extracted using a modified version of an organic extraction protocol ${ }^{63}$. We 24 used a lysis buffer containing $68 \mathrm{mM} \mathrm{N}$-lauroylsarcosine sodium salt, $50 \mathrm{mM}$ Tris-HCl $25(\mathrm{pH} 8.0), 150 \mathrm{mM} \mathrm{NaCl}$, and $20 \mathrm{mM}$ EDTA ( $\mathrm{pH}$ 8.0) and, immediately before 
1 extraction, $1.5 \mathrm{ml} \mathrm{2-mercaptoethanol} \mathrm{and} 1.0 \mathrm{ml} 1 \mathrm{M}$ DTT were added for each $30 \mathrm{ml}$

2 lysis buffer. Approximately $2 \mathrm{~g}$ of sediment was added, and $3 \mathrm{ml}$ of buffer, together

3 with $170 \mu \mathrm{g}$ of proteinase $\mathrm{K}$, and vortexed vigorously for $2 \times 20 \mathrm{~s}$ using a FastPrep-24

4 at speed $4.0 \mathrm{~m} \mathrm{~s}^{-1}$. An additional $170 \mu \mathrm{g}$ of proteinase $\mathrm{K}$ was added to each sample and

5 incubated, gently rotating overnight at $37^{\circ} \mathrm{C}$. For removal of inhibitors we used the

6 MOBIO (MO BIO Laboratories, Carlsbad, CA) C2 and C3 buffers following the

7 manufacturer's protocol. The extracts were further purified using phenol-chloroform

8 and concentrated using $30 \mathrm{kDa}$ Amicon Ultra-4 centrifugal filters as described in the

9 Andersen extraction protocol ${ }^{63}$. Our extraction method was changed from this protocol

10 with the following modifications: no lysis matrix was added due to the minerogenic

11 nature of the samples and the two phenol, one chloroform step was altered, thus both

12 phenol:chloroform:supernatant were added simultaneously in the respective ratio

13 1:0.5:1, followed by gentle rotation at room temperature for $10 \mathrm{~min}$ and spun for $5 \mathrm{~min}$

14 at 3,200g. For dark-coloured extracts, this phenol:chloroform step was repeated. All

15 extracts were quantified using Quant-iT dsDNA HS assay kit (Invitrogen) on a Qubit

162.0 Fluorometer according to the manufacturer's manual. The measured concentrations

17 were used to calculate the total ng DNA extracted per g of sediment (Fig. 2). 32 samples

18 were prepared for shotgun metagenome sequencing ${ }^{64}$ using the NEBNext DNA Library

19 Prep Master Mix Set for 454 (New England BioLabs) following the manufacturer's

20 protocol with the following modifications: (i) all reaction volumes (except for the end

21 repair step) were decreased to half the size as in the protocol, and (ii) all purification

22 steps were performed using the MinElute PCR Purification kit (Qiagen). Metagenome

23 libraries were amplified using AmpliTaq Gold (Applied Biosystems), given 14-20

24 cycles following and quantified using the 2100 BioAnalyser chip (Agilent). All libraries

25 were purified using Agencourt AMPure XP beads (BeckmanCoulter), quantified on the 
12100 BioAnalyzer and pooled equimolarly. All pooled libraries were sequenced on an

2 Illumina HiSeq 2500 platform and treated as single-end reads.

4 Bioinformatics. Metagenomic reads were demultiplexed and trimmed using

5 AdapterRemoval 1.5 (ref. 65) with a minimum base quality of 30 and minimum length

6 of $30 \mathrm{BP}^{66}$. All reads with poly-A/T tails $\geq 4$ were removed from each sample. Low-

7 quality reads and duplicates were removed using String Graph Assembler (SGA) ${ }^{67}$

8 setting the preprocessing tool dust-threshold $=1$, index algorithm $=$ 'ropebwt' and using

9 the SGA filter tool to remove exact and contained duplicates. Each quality-controlled

10 (QC) read was thereafter allowed equal change to map to reference sequences using

11 Bowtie2 version 2.2.4 (ref. 68) (end-to-end alignment and mode -k 50 for example,

12 reads were allowed a total of 500 hits before being parsed). A few reads with more than

13500 matches were confirmed by checking that the best blast hit belonged to this taxon,

14 and that alternative hits have lower e-values and alignment scores. We used the full

15 nucleotide database (nt) from GenBank (accessed 4 March 2015), which due to size

16 and downstream handling was divided into 9 consecutive equally sized databases and

17 indexed using Bowtie2-build. All QC checked fastq files were aligned end-to-end using

18 Bowtie2 default settings. Each alignment was merged using SAMtools ${ }^{69}$, sorted

19 according to read identifier and imported to MEGAN v. 10.5 (ref. 70). We performed

20 a lowest common ancestor (LCA) analysis using the built-in algorithm in MEGAN and

21 computed the taxonomic assignments employing the embedded NCBI taxonomic tree

22 (March 2015 version) on reads having 100\% matches to a reference sequence. We call

23 this pipeline 'Holi' because it takes a holistic approach because it has no a priori

24 assumption of environment and the read is given an equal chance to align against the

25 nt database containing the vast majority of organismal sequences (see Supplementary 
1 Information). In silico testing of 'Holi' sensitivity (see Supplementary Information)

2 revealed $0.1 \%$ as a reliable minimum threshold for Viridiplantae taxa. For metazoan

3 reads, which were found to be under-represented in our data, we set this threshold to 3

4 unique reads in one sample or 3 unique reads in three different samples from the same

5 lake. In addition, we confirmed that each read within the metazoans by checking that

6 the best blast hit belonged to this taxon, and that alternative hits have lower e-values

7 and alignment scores ${ }^{71}$. We merged all sequences from all blanks and subtracted this

8 from the total data set (instead of pairing for each extract and library build), using

9 lowest taxonomic end nodes. Candidate detection was performed by decreasing the 10 detection threshold in 'Holi' from $0.1 \%$ to $0.01 \%$ to increase the detection of 11 contaminating plants, and similar for metazoans, we decreased the detection level and 12 subtracted all with 2 or more reads per taxa (see Supplementary Information). We 13 performed a series of in silico tests to measure the sensitivity and specificity of our 14 assignment method and to estimate likelihood of false-positives (see Supplementary 15 Information).

We generated 1,030,354,587 Illumina reads distributed across 32 sediment samples and used the dedicated computational pipeline ('Holi’) for handling read de-multiplexing,

19 adaptor trimming, control quality, duplicate and low-complexity read removal (see 20 Supplementary Information). The 257,890,573 reads parsing filters were further 21 aligned against the whole non-redundant nucleotide (nt) sequence database ${ }^{72}$. Hereafter, 22 we used a lowest common ancestor approach ${ }^{70}$ to recover taxonomic information from 23 the 985,818 aligning reads. Plants represented by less than $0.1 \%$ of the total reads 24 assigned were discarded to limit false positives resulting from database mis-annotations, 25 PCR and sequencing errors (see Supplementary Information). Given the low number 
1 of reads assigned to multicellular, eukaryotic organisms (metazoans), we set a minimal

2 threshold of 3 counts per sample or 1 count in each of three samples. For plants and

3 metazoans this resulted in 511,504 and 2,596 reads assigned at the family or genus

4 levels, respectively. The read counts were then normalized for generating plant and

5 metazoan taxonomic profiles (Extended Data Figs 5 and 6). Taxonomic profiles for

6 reads assigned to bacteria, archaea, fungi and alveolata were also produced (see

7 Supplementary Information).

8

9 DNA damage and authenticity. We estimated the DNA damage levels using the 10 MapDamage package 2.0 (ref. 40) for the most abundant organisms (Extended Data 11 Fig. 7b). These represent distinctive sources, which help to account for potential 12 differences between damage accumulated from source to deposition or during 13 deposition. Input SAM files were generated for each sample using Bowtie2 (ref. 68) to 14 align all QC reads from each sample against each reference genome. All aligning 15 sequences were converted to BAM format, sorted and parsed through MapDamage by 16 running the statistical estimation using only the 5'-ends (-forward) for single reads. All

17 frequencies of cytosine to thymine mutations per position from the 5' ends were parsed 18 and the standard deviation was calculated to generate DNA damage models for each 19 lake (Extended Data Fig. 7a and Supplementary Information).

\section{References}

22 1. Haynes, C. V. Fluted projectile points: their age and dispersion. Science 145, 23 1408-1413 (1964).

$242 . \quad$ Ives, J. W., Froese, D., Supernant, K. \& Yanicki, G. M. Paleoamerican Odyssey, 149-169 (Texas A\&M University Press, 2013). 
1 3. Meiri, M. et al. Faunal record identifies Bering isthmus conditions as constraint to end-Pleistocene migration to the New World. Proc. Biol. Sci. 281, 20132167 (2014).

4. Shapiro, B. Rise and fall of the Beringian steppe bison. Science 306, 15611565 (2004).

5. Wilson, M. C., Hills, L. V. \& Shapiro, B. Late Pleistocene northward-

9. Gilbert, M. T. P. et al. DNA from pre-Clovis human coprolites in Oregon,

8. Dillehay, T. D. et al. Monte Verde: seaweed, food, medicine, and the peopling

6. Ferring, C. R. The archaeology and paleoecology of the Aubrey Clovis Site (41DN479). (Denton County, 2001).

7. Sanchez, G. et al. Human (Clovis)-gomphothere (Cuvieronius sp.) association 13,390 calibrated y BP in Sonora, Mexico. Proc. Natl. Acad. Sci. U.S.A. 111, 10972-10977 (2014). of South America. Science 320, 784-786 (2008).

North America. Science 320, 786-789 (2008).

10. Jenkins, D. L. et al. Clovis age Western Stemmed projectile points and human coprolites at the Paisley Caves. Science 337, 223-228 (2012).

11. Waters, M. R., Stafford, T. W., Jr., Kooyman, B. \& Hills, L. V. Late Pleistocene horse and camel hunting at the southern margin of the ice-free corridor: Reassessing the age of Wally’s Beach, Canada. Proc. Natl. Acad. Sci.

25 12. Dillehay, T. D. et al. New Archaeological Evidence for an early human 
presence at Monte Verde, Chile. PLoS ONE 10, e0141923 (2015).

13. Meltzer, D. J. First Peoples in a New World: Colonizing Ice Age America. (University of California Press, 2009).

14. Dyke, A. S. An outline of North American deglaciation with emphasis on central and northern Canada. Quaternary glaciations: extent and chronology. (Elsevier, Amsterdam), 371-406 (2004).

15. Dixon, E. J. Late Pleistocene colonization of North America from Northeast Asia: New insights from large-scale paleogeographic reconstructions. Quaternary Int 285, 57-67 (2013).

16. Buchanan, B. \& Collard, M. Investigating the peopling of North America through cladistic analyses of Early Paleoindian projectile points. Journal of Anthropological Archaeology 26, 366-393 (2007).

17. Haynes, G. Extinctions in North America’s Late Glacial landscapes. Quaternary Int 285, 89-98 (2013).

18. Madsen, D. B. A Framework for the Initial Occupation of the Americas. PaleoAmerica 1, 217-250 (2015).

19. Hickin, A. S., Lian, O. B., Levson, V. M. \& Cui, Y. Pattern and chronology of glacial Lake Peace shorelines and implications for isostacy and ice-sheet configuration in northeastern British Columbia, Canada. Boreas 44, 288-304 (2015).

20. Hickin, A. S., Lian, O. B. \& Levson, V. M. Coalescence of late Wisconsinan Cordilleran and Laurentide ice sheets east of the Rocky Mountain Foothills in the Dawson Creek region, northeast British Columbia, Canada. Quaternary Research, 1-21 (2016) In Press. doi:10.1016/j.yqres.2016.02.005

21. Munyikwa, K., Feathers, J. K., Rittenour, T. M. \& Shrimpton, H. K. 
Constraining the Late Wisconsinan retreat of the Laurentide ice sheet from western Canada using luminescence ages from postglacial aeolian dunes. Quat Geochronol 6, 407-422 (2011).

22. White, J. M., Mathewes, R. W. \& Mathews, W. H. Late Pleistocene chronology and environment of the 'ice-free corridor' of northwestern Alberta. Quaternary Research 24, 173-186 (1985).

23. Arnold, T. G. Radiocarbon dates from the ice-free corridor. Radiocarbon 44, 437-454 (2002).

24. Dixon, J. E. Human colonization of the Americas: timing, technology and process. Quaternary Sci Rev 20, 277-299 (2001).

25. Stork, A. Plant immigration in front of retreating glaciers, with examples from the Kebnekajse area, northern Sweden. Geografiska annaler 45(1), 1-22(1963).

26. Viereck, L. A. Plant succession and soil development on gravel outwash of the Muldrow Glacier, Alaska. Ecological Monographs 36(3), 181-199 (1966).

27. McCarthy, D. P. \& Luckman, B. H. Estimating ecesis for tree-ring dating of moraines: a comparative study from the Canadian Cordillera. Arctic Alpine Res 25(1), 63-68 (1993).

28. Mandryk, C. A. S., Josenhans, H., Fedje, D. W. \& Mathewes, R. W. Late Quaternary paleoenvironments of Northwestern North America: implications for inland versus coastal migration routes. Quaternary Sci Rev 20, 301-314 (2001).

29. Stokes, C. R., Margold, M., Clark, C. D. \& Tarasov, L. Ice stream activity scaled to ice sheet volume during Laurentide Ice Sheet deglaciation. Nature 530, 322-326 (2016).

30. Gowan, E. J. An assessment of the minimum timing of ice free conditions of 
the western Laurentide Ice Sheet. Quaternary Sci Rev 75, 100-113 (2013).

31. Mathews, W. H. Quaternary stratigraphy and geomorphology of Charlie Lake (94a) map-area, British Columbia. Canadian Geological Survey, 1-32 (1978).

32. White, J. M., Mathewes, R. W. \& Mathews, W. H. Radiocarbon dates from Boone Lake and their relation to the 'Ice-free Corridor' in the Peace River District of Alberta, Canada. Can. J. Earth Sci. 16, 1870-1874 (1979).

33. Hartman, G. \& Clague, J. J. Quaternary stratigraphy and glacial history of the Peace River valley, northeast British Columbia. Can. J. Earth Sci. 45, 549-564 (2008).

34. Birks, H. H. \& Birks, H. J. B. Quaternary Palaeoecology. (Edward Arnold, 1980).

35. Jass, C. N., Burns, J. A., Milot, P. J. \& Sues, H.-D. Description of fossil muskoxen and relative abundance of Pleistocene megafauna in central Alberta. Can. J. Earth Sci. 48, 793-800 (2011).

36. Kooyman, B., Hills, L.V., McNeil, P., Tolman, S. Late Pleistocene horse hunting at the Wally's Beach site (DhPg-8), Canada. Am Antiquity 71, 101-121 (2006)

37. Apland, B. \& Harington, C. R. Pleistocene Bison Skeleton (Bison bison cf. occidentalis) from Clayhurst Crossing, British Colombia. Géographie physique et Quaternaire 48, 213-233 (1994).

38. Burns, J. A. Mammalian faunal dynamics in Late Pleistocene Alberta, Canada. Quaternary Int 217, 37-42 (2010).

39. Driver, J. C., Handly, M., Fladmark, K. R. \& Nelson, D. E. Stratigraphy, radiocarbon dating, and culture history of Charlie Lake Cave, British Columbia. Arctic 49, 265-277 (1996). 
1 40. Kooyman, B., Hills, L., Tolman, S. \& McNeil, P. Late Pleistocene western camel (Camelops hesternus) hunting in southwestern Canada. Am Antiquity 71, 101-121 (2012).

41. Wilson, M. C. Late quaternary vertebrates and the opening of the ice-free corridor, with special reference to the genus bison. Quaternary Int 32, 97-105 (2002).

42. Willerslev, E. et al. Diverse plant and animal genetic records from Holocene and Pleistocene sediments. Science 300, 791-795 (2003).

44. Giguet-Covex, C. et al. Long livestock farming history and human landscape shaping revealed by lake sediment DNA. Nature communications 5, 3211 (2014).

45. Pedersen, M. W. et al. Ancient and modern environmental DNA. P Roy Soc BBiol Sci 370, (2015).

46. Alsos, I. G. et al. Sedimentary ancient DNA from Lake Skartjørna, Svalbard: Assessing the resilience of arctic flora to Holocene climate change. The Holocene 26, 627-642 (2015).

47. Parducci, L. et al. Molecular- and pollen-based vegetation analysis in lake sediments from central Scandinavia. Mol Ecol 22, 3511-3524 (2013).

48. Pedersen, M. W. et al. A comparative study of ancient environmental DNA to pollen and macrofossils from lake sediments reveals taxonomic overlap and additional plant taxa. Quaternary Sci Rev 75, 161-168 (2013).

49. Haile, J. S. et al. Ancient DNA reveals late survival of mammoth and horse in 
interior Alaska. PNAS 106, 22352-22357 (2009).

50. Parducci, L. et al. Glacial survival of boreal trees in northern Scandinavia. Science 335, 1083-1086 (2012).

51. Valentini, A., Pompanon, F. \& Taberlet, P. DNA barcoding for ecologists. Trends Ecol Evol 24, 110-117 (2009).

52. Coissac, E., Hollingsworth, P. M., Lavergne, S. \& Taberlet, P. From barcodes to genomes: extending the concept of DNA barcoding. Mol Ecol 25, 14231428. (2016). doi:10.1111/mec.13549

53. Faegri, K., Kaland, P. E. \& Krzywinski, K. Textbook of Pollen Analysis. 1-328 (John Wiley and Sons, 1990). doi:10.1002/jqs.3390050310

54. Bennett, K. D. Documentation for psimpoll 4.10 and pscomb 1.03. 1-127 (University of Uppsala, Sweden, 2005).

55. Wales, N., Andersen, K., Cappellini, E., Ávila-Arcos, M. C. \& Gilbert, M. T. P. Optimization of DNA recovery and amplification from non-carbonized archaeobotanical remains. PLoS ONE 9, e86827 (2014).

56. NCBI. Nt Database. [ftp://ftp.ncbi.nih.gov/blast/db/FASTA/nt.gz]. (2015).

57. Huson, D. H., Auch, A. F., Qi, J. \& Schuster, S. C. MEGAN analysis of metagenomic data. Genome Res 17, 377-386 (2007).

58. Jónsson, H., Ginolhac, A., Schubert, M., Johnson, P. L. F. \& Orlando, L. mapDamage2.0: fast approximate Bayesian estimates of ancient DNA damage parameters. Bioinformatics 29, 1682-1684 (2013).

59. Hickman, M. \& White, J. Late Quaternary palaeoenvironment of Spring Lake, Alberta, Canada. Journal of Paleolimnology 2, 305-317 (1989).

60. Godwin, H. Pollen analysis, An outline of the problems and potentialities of the method. Part I. Technique and interpretation. New Phytologist 33, 278-305 
(1934).

61. Harington, C. R. Quaternary cave faunas of Canada: A review of the vertebrate remains. Journal of Cave and Karst Studies 73, 162-180 (2009).

62. Beaudoin, A. B., Wright, M. \& Ronaghan, B. Late quaternary landscape history and archaeology in the 'Ice-Free Corridor’: Some recent results from Alberta. Quaternary Int 32, 113-126 (1996).

63. Hebda, R. J., Burns, J. A., Geertsema, M. \& jull, A. J. T. AMS-dated late Pleistocene taiga vole (Rodentia: Microtus xanthognathus) from northeast British Columbia, Canada: a cautionary lesson in chronology. Can. J. Earth Sci. 45, 611-618 (2008).

64. Potter, B. A., Holmes, C. \& Yesner, D. R. Paleoamerican Odyssey. 81-103 (Texas A\&M University Press, 2013). doi:10.2218/jls.v3i1.1337

65. Driver, J. C. \& Vallières, C. The Palaeoindian bison assemblage from Charlie Lake Cave, British Columbia. Canadian Journal of Archaeology/Journal Canadien 32(2), 239-257 (2008).

66. Matheus, P., Burns, J., Weinstock, J. \& Hofreiter, M. Pleistocene brown bears in the mid-continent of North America. Science 306, 1150 (2004).

67. Raghavan, M. et al. Genomic evidence for the Pleistocene and Recent population history of Native Americans. Science 349, aab3884-aab3884 (2015).

68. Rasmussen, M. et al. The genome of a Late Pleistocene human from a Clovis burial site in western Montana. Nature 506, 225-229 (2014).

69. Reasoner, M. A. Equipment and procedure improvements for a lightweight, inexpensive, percussion core sampling system. Journal of Paleolimnology 8, 273-281 (1993). 
1 70. Sandgren, P. \& Snowball, I. Tracking Environmental Change Using Lake Sediments: Volume 2: Physical and Geochemical Methods. 217-236 (Kluwer Academic Publishers, 2001).

4 71. Moore, P. D., Webb, J. A. \& Collison, M. E. Pollen analysis. 1-216 (Blackwell Scientific Publications, 1991).

6 72. Beug, H. J. Leitfaden der Pollenbestimmung. 74-90 (Verlag Dr. Friedrich Pfeil, 2004).

8 73. Brock, F., Higham, T., Ditchfield, P. \& Bronk Ramsey, C. Current pretreatment methods for AMS radiocarbon dating at the Oxford Radiocarbon

11 74. Staff, R. Wood Pretreatment protocols and measurement of tree-ring standards at the Oxford Radiocarbon Accelerator Unit (ORAU). Radiocarbon 56, 709-

14 75. Bronk Ramsey, C., Higham, T. \& Leach, P. Towards high-precision AMS: progress and limitations. Radiocarbon 46, 17-24 (2004).

16 76. Stuiver, M. \& Polach, H. Reporting of ${ }^{14} \mathrm{C}$ Data. Radiocarbon 19, 355-364 (1977).

18 77. Reimer, P. J., Bard, E., Bayliss, A. \& Beck, J. W. IntCal13 and Marine13 radiocarbon age calibration curves 0-50,000 years cal BP. Radiocarbon 55,

21 78. Bronk Ramsey, C. \& Lee, S. Recent and planned developments of the program OxCal. Radiocarbon 55(2-3), 720-730 (2013).

79. Bronk Ramsey, C. Deposition models for chronological records. Quaternary Sci Rev 27, 42-60 (2008).

80. Bronk Ramsey, C. Dealing with outliers and offsets in radiocarbon dating. 
Radiocarbon 51, $1023-1045$ (2009).

2 81. Meyer, M. \& Kircher, M. Illumina Sequencing Library Preparation for Highly Multiplexed Target Capture and Sequencing. Cold Spring Harb Protoc 2010, pdb.prot5448-pdb.prot5448 (2010).

5 82. Lindgreen, S. AdapterRemoval: easy cleaning of next-generation sequencing reads. BMC Res Notes 5, 337 (2012). www.nature.com/nature Nat Methods 9, 357-359 (2012).

86. Li, H. et al. The Sequence Alignment/Map format and SAMtools. Bioinformatics 25, 2078-2079 (2009).

87. Altschul, S. F., Gish, W., Miller, W., Myers, E. W. \& Lipman, D. J. Basic local alignment search tool. J Mol Biol 215, 403-410 (1990).

88. Bronk Ramsey, C. Bayesian Analysis of radiocarbon dates. Radiocarbon 51, 337-360 (2009).

\section{Acknowledgements}


1 We thank Mary Lynn Tobiaz, Tyler Murchie, Mel Reasoner, Keary Walde, Derek

2 Wilson, Farzin Malekani, Andrea Freeman, and the Danish National Sequencing Centre

3 for help and support. The study was supported by the Danish National Research

4 Foundation (DNRF94), the Lundbeck Foundation, and KU2016.

\section{Author contributions}

$7 \quad$ EW initiated and led the study. MWP, KHK, and EW designed and conducted the study.

8 AR, CS, HF processed and counted pollen and macrofossils. RAS performed the ${ }^{14} \mathrm{C}$ 9 dating and Bayesian age modelling. NKL and RAR scanned cores for XRF/MS. MWP 10 performed the molecular work under supervision by LO and EW. MWP, CS, ABB, 11 BAP, DJM, KHK and EW made the main interpretations of the results. MWP, DJM 12 and EW wrote the paper with input from all authors.

\section{Author information}

15 DNA sequence data will be uploaded to the NCBI SRA archive 16 http://www.ncbi.nlm.nih.gov/sra, pollen counts can be found at the North America 17 Pollen Database (NAPD)_http://www.neotomadb.org/ and bioinformatics scripts are 18 available at https://github.com/ancient-eDNA/Holi upon acceptance. Reprints and permissions information are available at www.nature.com/reprints

Correspondence and requests for materials should be addressed to

23 ewillerslev@snm.ku.dk 
2

3 


\section{Figure captions}

3 Figure 1 | Setting and study area. During the Last Glacial Maximum, the Laurentide

4 Ice Sheet and the Cordilleran Ice Sheet coalesced in western mid-Canada creating a

5 physical barrier to north-south migration. Following the Last Glacial Maximum, the

6 ice retreated creating an ice-free corridor (IFC). a, Ice extent ${ }^{10}$ during two periods, Last

7 Glacial Maximum 21.4 cal. kyr BP (off-white) and Late Pleistocene 14.1 cal. kyr BP

8 (light-blue). b, Topography of the Peace River basin with Glacial Lake Peace Phase III

9 (white lines with blue outlines) and Phase $\mathrm{IV}^{13}$ with ice extent ${ }^{10}$ (light-blue and dark-

10 blue) at around $14.1 \mathrm{cal}$. kyr BP and 13 cal. kyr BP, respectively. The red and white lines

11 mark topographic transects of the lakes which in relation to the four phases of Glacial

12 Lake Peace ${ }^{13}$ is found in Extended Data Fig. 1.

14 Figure 2 | Selected pollen, DNA and biometrical results. a, c, Pollen are presented 15 as influx (area) and DNA taxa presented with normalized counts (bars). HS asteraceae, 16 high spike asteraceae. Metazoans are presented with bullet points indicating their 17 presence. The 5 point average (5p) of the incoherent/coherent (incoh/coh) ratio is 18 derived from the $\mathrm{X}$-ray fluorescence results and an increasing ratio represents increased 19 organic content. b, d, Non-metric multi-dimensional scaling plots; grey ellipses marked 20 I, II, and III encircle the samples corresponding to the respective CONIIC pollen 21 zonation. Coloured dots indicate each taxon identified. The coloured categories are 22 identical to the pollen and DNA taxa in Charlie Lake (a), and Spring Lake (c). 
1 Timeline of the biology in the bottleneck area linking it with evidence of human

2 occupation and the first appearance of Clovis technology (see also Fig. 4). Grey animal

3 silhouettes are vertebrate genera that were identified by environmental DNA in both

$4 \quad$ lake cores.

5

6 Figure 4 | Colonization models. Comparison of models of Paleoindian colonization 7 (number of pulses, timing, and route(s)) that are supported or rejected by our data. All 8 ages are in calibrated years before present.

\section{Extended Data Figures}

\section{Extended Data Figure 1: Topographic transects.}

13 The red and white lines on Fig. 1b mark topographic transects of Charlie Lake and 14 Spring Lake in relation to the four phases of Glacial Lake Peace13. CIC, Cordilleran 15 ice complex; m.a.s.l., metres above sea level.

Extended Data Figure 2: Visual and physical descriptions and age-depth model for the studied lake sediments.

19 a, b, Charlie Lake (a) and Spring Lake (b) span the Pleistocene to Holocene transition

20 (dotted grey line); magnetic susceptibility (continuous black line); and compressed 21 high-resolution images from the ITRAX core scanner and the sedimentary log are 22 shown. Age-depth models for Charlie Lake (a) and Spring Lake (b) were generated

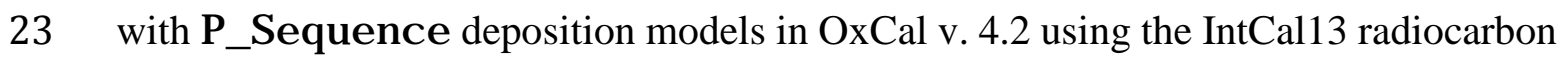
24 calibration curve $\mathrm{e}^{57,59,61}$. The probability envelopes represent the $68.2 \%$ and $95.4 \%$ 25 confidence ranges, respectively (see Methods and Supplementary Information). 
2 Extended Data Figure 3: Charlie Lake pollen and macrofossil diagrams.

3 a, Pollen are presented as influx and bullet points indicate taxa with less than 2 grains

$4 \mathrm{~cm}^{-2}$ year $^{-1}$. The diagram was zoned using CONIIC ${ }^{31}$ with a stratigraphically

5 constrained cluster analysis on the information statistic. b, Relative proportions of

6 ecologically important taxa. c, Macrofossils were identified but not enumerated. Bullet

7 points represent presence.

8

$9 \quad$ Extended Data Figure 4: Spring Lake pollen and macrofossil diagrams.

10 a, Pollen are presented as influx and bullet points represent taxa with less than 50 grains $11 \mathrm{~cm}^{-2}$ year ${ }^{-1}$. The diagram was zoned using CONIIC $^{31}$ with a stratigraphically 12 constrained cluster analysis on the information statistic. b, Relative proportions of 13 ecologically important taxa. c, Macrofossils were identified but not enumerated. Bullet 14 points represent presence.

Extended Data Figure 5: Charlie Lake DNA diagram.

17 DNA results are presented as normalized counts to allow comparison on the temporal 18 scale for each taxon. All are unique sequences with $100 \%$ sequence identity to taxa. 19 Histogram width equals the accumulation period. a, Viridiplantae, bullet points 20 represent counts less than 50. b, Algae, bullet points represent counts less than 50. c, 21 Metazoans, bullet points represent counts equal to 1.

23 Extended Data Figure 6: Spring Lake DNA diagram.

24 DNA results are presented as normalized counts to allow comparison on the temporal 25 scale for each taxon. All are unique sequences with $100 \%$ sequence identity to taxa. 
1 Histogram width equals the accumulation period. a, Viridiplantae, bullet points

2 represent counts less than 50. b, Algae, bullet points represent counts less than 50. c,

3 Metazoans, bullet points represent counts equal to 1.

4

5 Extended Data Figure 7: DNA damage accumulation model.

6 Maximum-likelihood DNA damage rates were estimated from nucleotide 7 misincorporation patterns using MapDamage2.0 (ref. 40). a, Each full circle is the mean 8 of cytosine to thymine mutation frequencies at the first position ( $\mathrm{n} \geq 2$ species) with 9 above 500 reads aligned to reference bars that represent \pm 1 s.d. b, Table of species used 10 for determining the DNA damage rates.

11

Extended Data Tables

13

14 Extended Data Table 1: AMS ${ }^{14} \mathrm{C}$ determinations of terrestrial plant macrofossil 15 samples from Charlie and Spring Lakes.

16 